\title{
米蛋白の脱脂粉乳およびアミノ酸による補足効果 Effect of Skim-milk and Pure Amino Acid Added to Polished Rice
}

(昭和 35 年 8 月 9 日受理)

\author{
渡 辺三 郎 \\ (Saburoh Watanabe)
}

Infant rats were fed on polished rice added with powdered skim-milk. The greatest effect was obtained with $25 \%$ skim-milk. As for the rats to which were given polished rice added with lysine and threonine and wheat protein simultaneously to maintain the nitrogen level, the same result was obtained as those administered with skim-milk.

緒 言

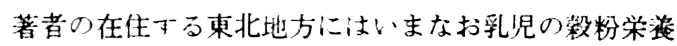
障害が跡索断たない。これら特に冬季感染に対する死 亡率が高く小児科医に上っては大きな関心事である。款 粉栄荃障害児の中に㳉母親の無知によるものも勿論ある が(教粉一主に米粉泣千チコと呼ばれ愛用される)，米粉 による栄盖つ不可を知りつつも経済的理由で，これに頼 らざる齐得ないのが奏情である。事実農村の主婦は過労 その他”母乳分䎵不全は意外:多く，一方新鮮牛乳を入 手する術はほ上ん上なく，未た市販乳呪用調製粉乳は現 金収入の乏しい農村にとっては極めて高価なものとなっ

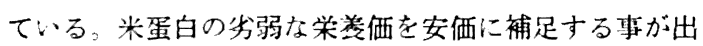
来れば特に乳児にとっても益するところが大きい。

きて近来この目的のために他の蛋白あるいはマミノ酸 添加が行われているが, 脱脂乳に依る補足についてはす でに Swaminathan 1) らの研究がある。氏は成熟白鼠を 用い主に白米に $10.4 \%$ の脱脂乳を添加して観察し，極め てよい成績をあげている。林2゙は幼弱ラッテを用い，15 \%脱脂乳食で発育のよくなるのを見ている。著者は白米 に脱脂乳を蛋白含有量 $13 \%$ になるように混入して幼弱う ッテの発育を見，一方白米に小表蛋白（馍）を矢張り蛋 白13\%にになるよう混入して，これにリジン (以下 Lys. と略記), スレオニン (以下 Thr. と略記)を添加して両 者を比較した。また白米に脱脂乳を添加する場合の最も 勃果的な添加量をも併せ検討した。

\section{実験および結果}

〔実験 1]白米に脱脂乳および白米+榇にLys. Thr. 添加の比較

ラッテはウィスター系雄で生後 21〜30 日，体重 40〜 $50 \mathrm{~g}$ の離乳直後のものを選んだ。一群 3 頭立てとし次の
8 群にわけた。

1. 白米 $(96)+$ 混合塩 (4)+綜合ビタミン $(0.2) \cdots$ 基喏 食

2. 基喏食 $+0.4 \%$ L-Lys. $-0.4 \% \mathrm{DL}-\mathrm{Thr}$.

3. 脱脂乳 $(96)+$ 混合塩 (4)

4. 白米 (72) +脱脂乳 (24) +混合塩 (4) ……(蛋白質 $12.95 \%$ )

5. 第 4 群食 $+0.4 \%$ L-Lys. $+0.4 \%$ DL-Thr.

6. 白米 $(65)+$ 麩 $(31)+$ 混合塩 (4)…(蛋白啠 $13.00 \%$ )

7. 第 6 群食 $+0.4 \%$ L-Lys. $+0.4 \%$ DL-Thr.

8. オリエンタル固形铝料

白米は市販精製白米粉を用い，混合㙁は Phillip Hant $^{3)}$ のものを，また棕合ビタミン剂はポポン末を用 い, 各群に添加し佴は粉末のまま自由食にした。 Lys. および Thr. は田辺製薬提供のものを用いた。脱脂乳は 市贩雪印スキムミルクを用いた。各群について体重, 尾 長を週 2 回測定し, 血球数, 血清蛋白, 血色素量を 2 週 間每に測定して1カ月飼育後屠殺, 剖見した。なお血清 蛋白は蛋白計により, 血色素量はシアンヘマチン法によ った。

〔結果 1〕第 1 表に示した。すなわち白米に脱脂乳を 添加した群では，発育が極めて良好で, ほぼオリンンタル 固形飼料群に匹敵している。一方白米に堵を添加しただ けでは別に成長はよくはならないが, これに Lys. Thr. を同時補足すると極めで発育がよく、 スキム添加群に劣 らない。しかも白米のみに Lys. Thr. を添加した場合よ. りもよい結果を得た。これに対して, 脱脂乳添加群にLys. Thr. を添加してもよくはならずかえって幾分劣る結果 を得た。脱脂乳のみの群では発育が悪く, 中途で(11日 目） 2 頭注栄養障害著しく死亡した。残り 1 頭が発有し たが，他群に比べ毛立が悪く，酸醉性下利に傾き鼓晹を 来していた。血液には著変は出ない。 
第13拳 4 第

第 1 表 白米に脱脂乳添加時及び白米+矨に Lys. Thr. 添加時の成舆及び血液性状

\begin{tabular}{|c|c|c|c|c|c|c|c|c|c|}
\hline & & $\begin{array}{l}\text { G. } 1 \\
\text { 白米 }\end{array}$ & $\begin{array}{l}\text { G. } 2 \\
\text { 白米+ } \\
\text { Lys. Thr. }\end{array}$ & $\begin{array}{l}\text { G. } 3^{*} \\
\pi \neq 4 \leqslant n\}\end{array}$ & 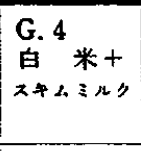 & 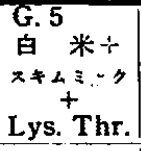 & $\begin{array}{l}\text { G. } 6 \\
\text { 白米十継 }\end{array}$ & $\begin{array}{l}\text { G. } 7 \\
\text { 白米+就 } \\
\text { Lys. Thr. }\end{array}$ & $\begin{array}{l}\text { G. } 8 \\
\text { ホリエンタn } \\
\text { 餜 料 }\end{array}$ \\
\hline 平均体重增㛎 & $\mathbf{g}$ & 44.5 & 103.3 & 104.0 & 148.0 & 121.7 & 31.0 & 126.7 & 153.5 \\
\hline 平均尾長增加 & $\mathrm{mm}$ & 27.0 & 49.0 & 43.0 & 64.0 & 51.0 & 21.3 & 51.3 & 55.0 \\
\hline 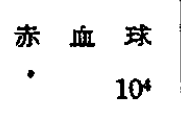 & $\begin{array}{l}\text { 第1回， } \\
\text { 第 } 2 \text { 回 } \\
\text { 第3回 }\end{array}$ & $\begin{array}{l}809.0 \\
885.0 \\
826.0\end{array}$ & $\begin{array}{l}725.7 \\
886.0 \\
916.3\end{array}$ & $\begin{array}{l}725.3 \\
932.0 \\
989.0\end{array}$ & $\begin{array}{l}766.0 \\
689.0 \\
937.0\end{array}$ & $\begin{array}{l}801.7 \\
886.0 \\
960.7\end{array}$ & $\begin{array}{l}718.0 \\
842.0 \\
892.7\end{array}$ & $\begin{array}{l}581.0 \\
723.0 \\
858.0\end{array}$ & $\begin{array}{r}- \\
793.5 \\
925.5\end{array}$ \\
\hline $\begin{array}{r}\text { 白 的 } \\
10^{3}\end{array}$ & $\begin{array}{l}\text { 第1回 } \\
\text { 第2回 } \\
\text { 第3回 }\end{array}$ & $\begin{array}{r}4.85 \\
8.10 \\
11.65\end{array}$ & $\begin{array}{l}9.50 \\
7.03 \\
8.90\end{array}$ & $\begin{array}{l}6.73 \\
8.60 \\
8.90\end{array}$ & $\begin{array}{l}8.50 \\
7.55 \\
6.55\end{array}$ & $\begin{array}{r}8.53 \\
8.50 \\
12.90\end{array}$ & $\begin{array}{r}6.17 \\
6.43 \\
10.87\end{array}$ & $\begin{array}{l}8.33 \\
6.50 \\
9.00\end{array}$ & $\begin{array}{r}- \\
7.65 \\
9.40\end{array}$ \\
\hline $\begin{array}{r}\text { 血清蛋卢 } \\
\qquad / \mathrm{g} / \mathrm{l}\end{array}$ & $\begin{array}{l}\text { 第1 回 } \\
\text { 第 } 2 \text { 回 } \\
\text { 第 } 3 \text { 回 }\end{array}$ & $\begin{array}{l}4.70 \\
5.25 \\
5.70\end{array}$ & $\begin{array}{l}5.03 \\
5.43 \\
6.13\end{array}$ & $\begin{array}{l}6.40 \\
5.20 \\
5.70\end{array}$ & $\begin{array}{l}5.35 \\
5.85 \\
6.60\end{array}$ & $\begin{array}{l}6.00 \\
5.87 \\
6.77\end{array}$ & $\begin{array}{l}5.13 \\
5.60 \\
6.20\end{array}$ & $\begin{array}{l}5.40 \\
5.68 \\
6.37\end{array}$ & $\begin{array}{r}- \\
5.90 \\
6.30\end{array}$ \\
\hline $\begin{array}{l}\text { 血 色 素 } \\
\mathrm{mg} / \mathrm{dl}\end{array}$ & $\begin{array}{l}\text { 第1回 } \\
\text { 第 } 2 \text { 回 } \\
\text { 第3回 }\end{array}$ & $\begin{array}{l}14.30 \\
14.75 \\
14.95\end{array}$ & $\begin{array}{l}15.73 \\
14.80 \\
15.23\end{array}$ & $\begin{array}{l}16.63 \\
17.00 \\
19.90\end{array}$ & $\begin{array}{l}15.10 \\
15.15 \\
19.75\end{array}$ & $\begin{array}{l}15.77 \\
16.03 \\
16.83\end{array}$ & $\begin{array}{l}15.27 \\
15.67 \\
16.23\end{array}$ & $\begin{array}{l}15.60 \\
15.40 \\
16.33\end{array}$ & $\begin{array}{r}- \\
15.35 \\
16.65\end{array}$ \\
\hline
\end{tabular}

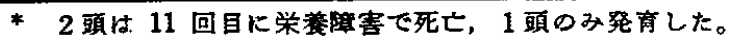

〔実稌 2]白米に添加する脱脂乳の量と発育との関保 上記の目的で次の7群にわけて䂓察した。実験材料そ の他仕前と同とである。

1. 脱脂乳のみ (100)

2. 脱脂乳 $(50)+$ 白米 $(491+$ 混合塩 $(1)+$ クエン酸鉄 0.1

3. 脱脂到(25)+白米.72-混台程(3)+クエン酸跌 0.05

4. 脱脂乳 $12: \div$ 白米 84 : 一混合塩(4)

5. 脱脂乎 $(6)+$ 白米 $(90)+$ 混合塩 $(4)$

6. 帨脂我 $(3)+$ 白米 931 - 混台塩(4)

\section{7. 白米(96)+混合塩 (4)}

各群に綜合ビタミン (ポポン末) 0.2 加え G. 1 3 には鉄欠乏性角血を防ぐ意味でクエン酸鉄を与えた。こ れらについて前回同様成長を，血液では血清蛋白量を測 定した。

[結果]第 2 表およひ図に示した。脱脂粉乳のみの群 はやはり毛並が悪く，発㕕不良かつまちまちである。脱 脂乳添加は $25 \%$ 位が最も効果的のように見える。

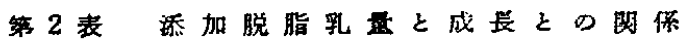

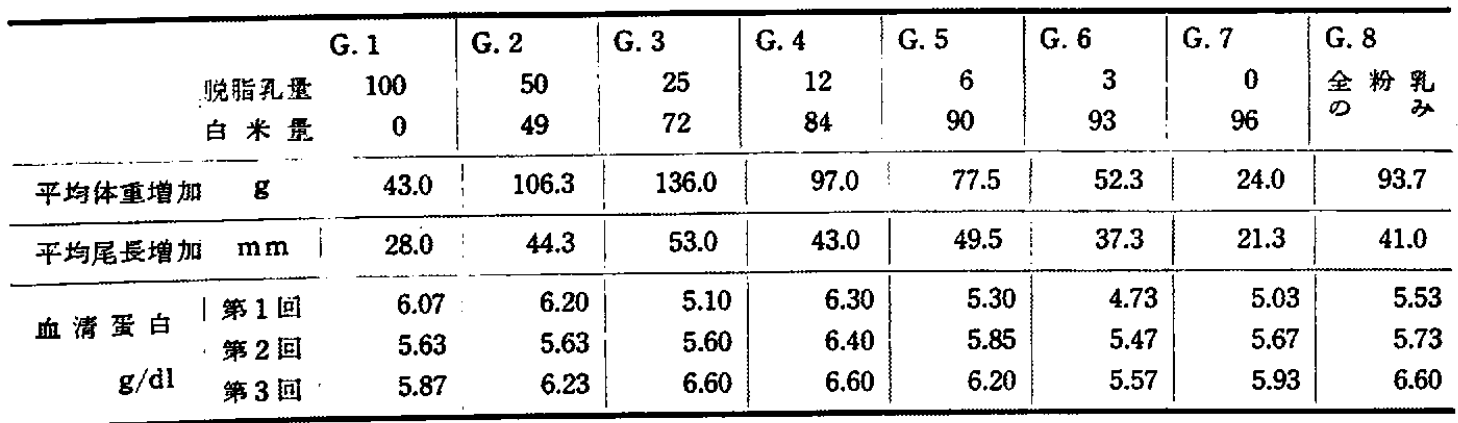


第 1 园添加脱脂乳勘と体重增加との成保 ( $\times$ 印は平均值)

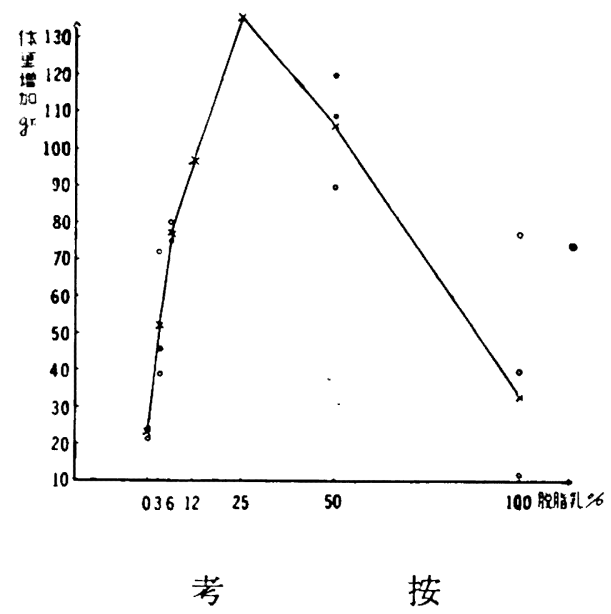

白米に脱脂乳を添加すると発育のよくなる平仕前から 判っていた事であるが，この実験により添加似25\%が最 適で，この量を越えるとかえって発育は遅れる事が解っ た：脱脂乎25\%添加で，総蛋白䂽は約 $13 \%$ になるが，白 米に碀を混じて蛋白量を矢張り13\%。に，これにLys. Thr．を加えた場合においても，前者に匹敵するよい発 育を見た。白米にLys. Thr. 添加だけではこれだけの発 育は期待出来なかった。これは小麦蛋白に対するLys.の
成長促進作用と白米に対する Lys. Thr. の促進作用が 相俟って好結果を得たものと考えたい。

この実験の場合植物蛋白にアミノ酸を補足する事によ りほほ㗢物蛋白並の効果が得られた事になる。

脱脂粉乳のみで飼育すると，毛並は悪く，発育振りも 個体差が強く，多くは豉脂，酸醉性下淿を呈して来た。 これらの理由については稿を改めてまた報告したい。

\section{結論}

白米に対する脱脂乳添加然は $25 \%$ で最も効果的であ る。白米に麩を混入して総N量を高め,これにLys. Thr. を添加してを，脱脂乳添加に匹敵する発育を来した。脱 脂乳のみでは良好な発育は出来ない。

擱籊に当り御愁第な御指導御校閲を賜わった東大教授 吉川春买先生並びに終始御鞭撻下さった詫摩武人名誉教 授に媣甚なる感谢を捧げます。また本研究に種々御援助, 御好意を镹くしている太田綜合病院長太田辰雄博士に鳴 旍いたします。

\section{文献}

1) Swaminathan, M.: Ind. J. Med. Res. 25, 399 (1937)

2) 林: 福阊医雑, 47, 1092 (1957)

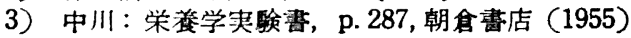

（郡山太田病院小児科）

\section{肥满者の糖留代腤}

かなり長い間肥満状態が続いている婦人で，家族歴に も既往䄳にも糖尿病がない人は，経口的にブドウ糖を与 えた場合の耐榶力が健康人よりも劣り，食事前の血榶值 がやや高、傾向がある。ところが，このような人の静脈 内にプドウ螗を投与したときの血榶値の減少速度は正常 であるし，また血中ピルビン酸の增加具合も正常であ る。このことは，肥渾状態が長い間続いている人に対し ては, 軽い糖尿病の有無の診断は, 経口的にブドウ糖を 投与して耐榶曲線をみただけでは不確実であることを示 す。ガラクトースを経口的に投与したときの血中ガラク
トース量は, 肥満者の場合, 正常者に比して上晋度が少 なく，また静脈内に注射したときの減少度は大きい。す なわち肥満者の肝贜のグリコゲン生成力は低下していな r.

Observations on Carbohydrate in Metabolism in Obesity

W. L. Morse, J. J. Sidorov, J. S. Soeldner and R. C. Dickson

Metabolism 9, 666 (1960) 